\title{
Innovation in Territorial Governance: the Case of Agricultural Districts in Lombardy Region
}

\author{
Stefano Corsi ${ }^{1, a}$, Chiara Mazzocchi ${ }^{2, b}$, Federica Monaco ${ }^{2, \mathrm{c}}$ and Guido Sali ${ }^{2, \mathrm{~d}}$ \\ ${ }^{1}$ DEMM, Università degli Studi di Milano, via Celoria, 220133 Milano, Italy \\ ${ }^{2}$ DiSAA, Università degli Studi di Milano, via Celoria, 220133 Milano, Italy

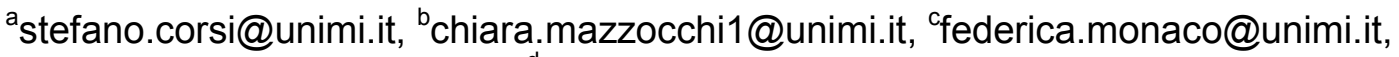 \\ guido.sali@unimi.it,
}

Keywords: District, Agricultural District, Governance Innovation.

\begin{abstract}
In recent years globalization and the economic crisis have been pressing the agricultural sector, driving farmers to adopt new tools in order to deal with the challenges put in place by a globalized market and by the actions of agricultural policies.

In this sense, the Italian legislation allows them joining in organized superstructures that, referring to the concept of industrial district, involve different members of a specific production sector in a territorial context, in a network of relationships and a higher vertical and horizontal integration. Under these drivers, agricultural rural districts, agro-food quality districts and supply chain districts have been constituted. They represent concrete examples of a new form of territorial governance that may play a role in the development and enhancement of the local area and its agro-food production. Three districts belonging to different categories operating and recognized by Lombardy region have been taken as case studies, and a set of qualitative criteria and indicators is proposed, in order to provide a framework of their characteristics and a preliminary comparison among them and their impacts.
\end{abstract}

\section{Introduction}

In recent years globalization and the economic crisis have been pressing the agricultural sector to deal with substantial changes that have often mainly affected SMEs [1]. Agricultural policies and new market challenges urge farmers to find alternative ways for the economically sustainable development of their activities allowing a long-term entrepreneurial vision. It emerges the need to identify new and innovative elements and tools for strengthening farm competitiveness; the district represents an example of this strategy, as a network of relationships amongst enterprises, institutions and local population, which allows sharing resources and knowledge, through an operative model focused on participation. A local production system contributes to its typical productions and services, through a division of work among efficient enterprises in competition with each other [2]. The crucial elements of the district are then the presence of a cooperation network amongst enterprises, integration, quality and distinctive skills of the work. A high number of small and medium-sized enterprises, individuals with a high social mobility and a public administration contribute to its economic growth, while the economic and social structure is guaranteed by informal rules, subjected to entrepreneurial risk, distributing profit and losses [3].

The concept of "district" in the 90's Italian regulation provided normative definitions of industrial districts, forms of aggregation of SMEs and highly specialized sectors, characterizing a territory economically, socially and environmentally [5]. Regulation no. 317 of 1991, defined them as "geographical areas characterized by high concentration of small businesses, with particular reference to the relationship between the presence of firms and the resident population as well as the specialization of the companies" [6] the latest regulation no 140 of 1999 stated them as "local production systems, characterized by a high concentration of industrial enterprises as well as the specialization of business systems" [7].

The agricultural district can be then considered a particular form of industrial district, and at national level, Italian Agricultural Act [8] introduced the possibility to make concrete their 
promotion and development. They represent a new model of economic organization realized through a form of aggregation of different subjects, with strong interdependencies between farms, enterprises and agro-food industries, in a closer vertical and horizontal integration among production, processing and distribution, finally resulting in a business-to-business marketing scheme. The establishment of agricultural districts is subjected to an accreditation procedure in the competent region(s) after which, a company district is set up and governed by a proper statute, while initiatives and interventions are described and planned in a specific District Plan.

Their introduction and development aim to:

- promote and improve agricultural competitiveness, favoured by the integration with the context, particular relationships and network among different agents, typically not only belonging to the same sector;

- integrate different actors involved in the food supply chain in a specific territory and their actions (e.g. tourism, craft, ...), in a structure made of mainly SMEs; encourage shared and integrated strategies for a coordinated action, without any leading production, even to support innovation and internationalization in chains;

- promote activities and programs for local development and valorisation: involved actors and stakeholders have a strong territorial identity, resulting in credence attributes of local development based on environmental quality and sustainability, landscape, local culture;

- facilitate and strengthen local governance, providing support to the organization of rural economy and playing an important role in the territorialisation of policies and as a tool for a "strong" local governance [9].

\section{Agricultural districts in Lombardy Region}

National regulation states the descriptions and definitions of two typologies of agricultural district:

- rural districts, from which it emerges the concept of a multifunctional, locally-based agriculture: "Local productive systems characterized by an homogenous historical and territorial identity deriving from the integration between agricultural activities and other local activities, as well as from the production of goods or services of particularly specificity, consistent with natural and territorial traditions and vocations" [8, art.13]

- quality agro-food districts. "Local productive systems, even interregional, characterized by a significant economic presence and one or more certified ant protected productions [...], or traditional and typical productions" [8, art.13].

In addition, Lombardy Region has implemented and further enlarged National regulation introducing the category of food chain districts, as "high-specialized and sector production systems, characterized by a strong integration amongst operators of a chain and by significant representation in economic terms at sector and regional level" [10, art. p. 2606], allowing different subjects to join the organization, and in particular:

- agricultural and agro-food industries, either individual or associated;

- consortia made up of individual and/or associated farms, operating in processing and/or distribution of agricultural products;

- individual or associated enterprises operating in chains directly linked to agricultural activities (e.g. tourisms, craft, local production activities);

- other subjects and stakeholders (e.g. Park Authority, local Authorities, Local Action Groups, tourist and cultural systems, school systems).

With this latest introduction, Lombardy Region currently counts 23 districts that refer to different agricultural sectors and productions (fruits and vegetables, nurseries, livestock, cereals, dairy products, wine): 10 food chain districts, 10 rural districts and 3 quality districts [11]. 


\section{Methodology and results}

Three agricultural districts operating in Lombardy were been chosen as case studies, one for each typology stated by regulations: "Riso e rane", for the rural typology, "Distretto della filiera ORtoFrutticola" (DORF) for the chain typology and "Bonarda e Pinot Nero dell'Oltrepò Pavese" (OP) as quality typology. A descriptive overview in qualitative and quantitative terms is summarized in table 1. The different size of the districts emerges: rural and quality districts are similar for the number of partners involved and they are both located in a specific area of the region, where production is concentrated and eventually even the processing of the product.

The features of the chain districts are instead more complex. By its own definition, it implies a higher number of members, leading to not immediate understanding and identification of its organizational structure.

Table 1: Brief description of case study districts

\begin{tabular}{|c|c|c|c|c|c|c|c|c|c|c|}
\hline & \multirow{2}{*}{ Typology } & \multirow{2}{*}{$\begin{array}{c}\text { Main } \\
\text { products }\end{array}$} & \multirow{2}{*}{ Location } & \multirow{2}{*}{ Production } & \multicolumn{6}{|c|}{ Subjects involved } \\
\hline & & & & & Total & Producers & $\begin{array}{l}\text { Associa- } \\
\text { tions }\end{array}$ & Processors & $\begin{array}{l}\text { Distri- } \\
\text { butors }\end{array}$ & Others* \\
\hline $\begin{array}{l}\text { Riso e } \\
\text { Rane }\end{array}$ & Rural & Rice & $\begin{array}{l}\text { Province of } \\
\text { Milan }\end{array}$ & $\begin{array}{c}>25,000 \\
\text { tons }\end{array}$ & 63 & 63 & & & & \\
\hline DORF & Chain & $\begin{array}{c}\text { Fruits } \\
\text { and } \\
\text { vegetables }\end{array}$ & $\begin{aligned} & \text { Lombardy } \\
+ & \text { other regions }\end{aligned}$ & $\begin{array}{c}>670,000 \\
\text { tons }\end{array}$ & 1,751 & 1,675 & $\begin{array}{l}13 \text { (OP) } \\
(2 \text { AOP) }\end{array}$ & 36 & 21 & 6 \\
\hline$O P$ & Quality & Wine & Oltrepò pavese & $\begin{array}{c}>8,000,000 \\
\text { bottles }\end{array}$ & 72 & 68 & & 4 wineries & & \\
\hline
\end{tabular}

* firms for external services (e.g. seeds, greenhouses and irrigation, machinery, microbiological analyses, packaging).

Afterwards, the distinctive features of the district structure have been considered as parameters for a qualitative evaluation of the district itself:

A. product innovation concerns with the specificity in the production process of item or services related to the district and their quality in terms of innovation in comparison with actual supply;

B. know-how and process innovation along the production process;

C. participation degree of different subjects in a common organization, able to make their contribution economically and socially integrated;

D. organizational degree representing the management structure of the district;

E. territorial benefits, or positive impacts on the territory where the district operates, at economic, social and environmental level;

F. propensity for innovation, meant as the degree of the involvement of Universities or research institutes in the district development projects;

G. existence of a trademark, as a proxy for the level of organization and commercial advertising of the district.

In table 2 these different components are summarized per district, according to the sphere of impact their effects have on the territory: the environmental (ENV) sphere, the social (SOC) and the economic (ECO) ones. This step focuses on the parameters playing a role for the evaluation of the innovative degree that in governance innovation the district promotes. The results are exposed in table 2.

Table 2: Qualitative evaluation of case studies districts - evaluation parameter and impact contexts

\begin{tabular}{|l|c|c|c|c|c|c|c|}
\hline & A & B & C & D & E & F & G \\
\hline $\begin{array}{l}\text { Riso } \boldsymbol{e} \\
\text { Rane }\end{array}$ & ENV & ECO & SOC & SOC & $\begin{array}{l}\text { ECO } \\
\text { SOC } \\
\text { ENV }\end{array}$ & SOC & $\begin{array}{l}\text { ECO } \\
\text { SOC }\end{array}$ \\
\hline DORF & & ECO & SOC & SCO & ECO & & \\
\hline $\boldsymbol{O P}$ & & & SOC & SOC & ECO & & SOC \\
\hline
\end{tabular}


"Riso e Rane" stands out for innovations in food chain organization, to serve as organizational and managerial superstructure able to act as a reference subject for associated farms and other actors along the chain; promoted actions- certification of seeds, checked DNA, definition of qualitative parameters, aim to define a virtuous path towards productive parameters counting for quality as a whole (product, process and environment) [12]. The involvement of Universities adds the value of propensity to innovation, allowing a long term-view in terms of choices.

DORF is a chain district characterized by a high level of participation, involving different kind of enterprises and industries and the adoption of innovative managerial strategies, up to a greater coordination amongst food supply chains and to the promotion of initiatives targeted to citizens and focused on an aware consumption, through a direct relationship with schools. It is made up of members who may not be directly linked to production processes, but rather providers for other services, and two associations of producer organizations (AOP). These latter are in turn made up of producer organizations (OP) that constitute themselves a sort of small food chain within the larger AOP, towards which they converge their own productions, whether fresh or processed.

Finally, OP quality district represents an "instrument for territorial management, integrated with planning and territorial development tools" [13] and aims to qualify, consolidate and characterize the socio-economic development of the area of wine production, through a participatory approach involving public and private subjects. It returns in a strong local relapse, even for the revitalizing an agricultural system in an "less favored area" by RDP.

\section{Conclusions}

The actual situation of both agricultural policies and global market, encourage agro- ad agrofood enterprises and farms to promote development projects expanded to other subjects. Considering the territorial elements characterizing the area, institutions have implemented the tool of the District, which allows innovation in local governance thanks to the construction and exploitation of the network of relationships among companies, institutions and local populations, finally resulting in the share of resources and knowledge, through a formula focused on "participation". The paper classifies the districts according to the their features and evaluating their degree of innovation through an array of qualitative innovation indicators.

\section{References}

[1] C. Mazzocchi and G. Sali: Classification of Geographical Indication: a proposal of codification, Journal of Intellectual Property Rights, Vol 17, (2012) pp.218-225

[2] M. Bellandi: Struttura e cambiamento economico nei distretti industriali in: Sistemi produttivi locali: struttura e trasformazione, G. Garofoli and R. Mazzoni, Franco Angeli, Milano (1994)

[3] E. Basile and C. Cecchi: La trasformazione post-industriale della campagna. Dall'agricoltura ai sistemi locali rurali. Rosenberg \& Sellier, Torino (2001)

[5] DG Agricoltura Regione Lombardia: Distretti agricoli in Lombardia. Conference "Distretti agricoli promotori di innovazione: il caso Lombardia". Information on: http://www.agricoltura.regione.lombardia.it/shared/ccurl/159/812/Cosmina\%20Colombi,0.pdf/

[6] Legge 5 ottobre 1991, n. 317 Interventi per l'innovazione e lo sviluppo delle piccole imprese. G.U. n.237, 9 ottobre 1991 - Suppl. Ordinario n. 60

[7] Legge 11 maggio 1999, n. 140 "Norme in materia di attività produttive". G.U. n. 117, 21 maggio 1999

[8] Legislative Decree no. 228 of 2001 “Orientamento e modernizzazione del settore agricolo, a norma dell'articolo 7 della legge 5 Marzo 2011, n. 57”. G.U. n. 137, 15 Giugno 2001 Supplemento Ordinario n. 149 
[9] G. Belletti and A. Marescotti in: LEADER e distretti rurali - sinergie e complementarietà. Working paper, Rete Nazionale per lo Sviluppo Rurale, ed. (2007)

[10] Legge Regionale 23 Gennaio 2007, n. 1 "Strumenti di competitività per le imprese e per il territorio della Lombardia". BURL 5 Febbraio 2007

[11] Delibera Regione Lombardia n. 900, BURL 12 novembre 2013, serie ordinaria n. 46

[12] M. Magni: Distretto Riso e Rane, Buono, Sano e Vicino. Information on: http://users.unimi.it/ disaa/upload/consiglidisaa/15072013Riso\%20e\%20Rane\%20progetto\%2 0finale_Bocchi_Marino_Bechini.pdf/

[13] information on http://oltrepòpavese.com/ 